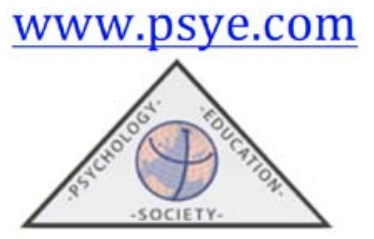

(c) Psychology, Society, \& Education, 2017. Vol. 9(1), pp. 11-26

ISSN 2171-2085 (print) / ISSN 1989-709X (online)

\title{
The effect of a professional development program workshop about problem solving on mathematics teachers' ideas about the nature of mathematics, achievements in mathematics, and learning in mathematics
}

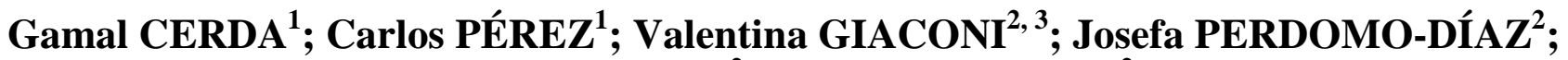 Cristián REYES ${ }^{2}$ \& Patricio FELMER ${ }^{2}$}

${ }^{1}$ University of Concepción, Chile. ${ }^{2}$ University of Chile ${ }^{3}$ University of Grenoble-Alpes, France.

(Received on April 2, 2016; Accepted on June 10, 2016)

\begin{abstract}
Results are presented about the effect of a professional development workshop (hereinafter PDW) for mathematics teachers regarding their beliefs about mathematics $(\mathrm{N}=82)$. The workshop, titled RPAula, was aimed at primary school teachers and it focused on problem solving (hereinafter PS). The teachers beliefs under study are related to the nature of mathematics, the learning of mathematics and achievement in mathematics, as well as to the type of practices, experiences, and assessments of the importance of PS and the use of PS in the classroom.

The results showed that by participating in the PDW, teachers weakened their ideas about mathematics being a rigid, structured and eminently formal process. Likewise, participation in the PDW also lessened teachers' perceptions of their leading roles during the learning process, increasing their appraisal of PS practices that are student-centered. It was also noted that teachers' perception that access to mathematics learning is a fixed condition or an unalterable fact associated with students' innate abilities, gender or ethnic stereotypes, also diminished. In addition, teachers reported improvements in their self-perception of competence and self-efficacy to implement PS in the classroom with their students. These findings and their implications for mathematics learning and teaching are discussed in this article.
\end{abstract}

Keywords: Problem solving, mathematics, beliefs, achievement and learning, primary education.

El efecto de un taller de desarrollo profesional sobre la resolución de problemas de las ideas de los profesores de matemáticas sobre la naturaleza, los logros y el aprendizaje en matemáticas

RESUMEN: Se presentan los resultados de un taller de desarrollo profesional (PDW) para maestros de matemáticas sobre sus creencias sobre matemáticas $(\mathrm{N}=82)$. El taller, titulado RPAula, estuvo dirigido a profesores de primaria y se centró en la resolución de problemas (en adelante PS). Las creencias de los profesores en el estudio están relacionadas con la naturaleza de las matemáticas, el aprendizaje de las matemáticas y los logros en matemáticas, así como con el tipo de prácticas, experiencias y evaluaciones de la importancia del PS y el uso del PS en el aula. Los resultados mostraron que al participar en la PDW, los maestros debilitaron sus ideas acerca de que las matemáticas fueran un proceso rígido, estructurado y eminentemente formal. Asimismo, la participación en la PDW también 
disminuyó la percepción de los maestros sobre sus roles de liderazgo durante el proceso de aprendizaje, incrementando su valoración de las prácticas de PS centradas en los estudiantes. También se observó que disminuyó la percepción de los profesores de que el acceso al aprendizaje de las matemáticas es una condición fija o un hecho inalterable asociado con las habilidades innatas de los estudiantes, el género o los estereotipos étnicos. Además, los maestros reportaron mejoras en su autopercepción de competencia y autoeficacia para implementar PS en el aula con sus alumnos. Se discuten estos hallazgos y sus implicaciones para el aprendizaje y la enseñanza de matemáticas y la enseñanza.

Palabras clave: Resolución de problemas, matemáticas, creencias, logros y aprendizaje, educación primaria.

Correspondence: Department of Research Methodology and Education Informatics, Faculty of Education at the University of Concepción, Chile. gamal.cerda@udec.cl

Problem solving is one of the four mathematical abilities explicitly declared in the Chilean education curriculum. Namely, these abilities are to argue and to communicate, to represent, to model, and, to solve problems (Mineduc, 2012). In this respect, it is plausible to state that the ability of PS is an axial axis for the other three previously mentioned abilities, because when students solve problems, they also need to be able to represent and to model as well. Likewise, PS tasks provide the opportunity to communicate and to express the mathematical reasoning that leads to obtaining solutions. In addition, PS tasks also develop the necessary skills to argue the validity of solutions, the ability to take in observations from peers, and the ability to describe mistakes or initial work processes, especially in the case of group work.

The skills associated to PS are an essential part of the cognitive domains of international educational assessments. Namely, tests like TIMSS or PISA include problems, which demand students to apply mathematical concepts and use mathematical reasoning to justify and support their answers. Consequently, problem solving, modeling skills, representation skills, and mathematical reasoning have an undoubtedly importance when facing educational assessments. From the point of view of learning, PS promotes and enhances the development of multiple skills, such as examining, representing, and, implementing. Likewise, it also provides training in the use of processes associated to advanced mathematical thinking, such as abstracting, analyzing, conjecturing, generalizing or synthesizing (National Research Council, 2001; Niss, 2002).

However, the acquisition of PS may be hindered if teacher themselves have not experienced PS. Polya (1954) clearly stated this, when he affirmed that teachers should experience the initial tension of mental block and the subsequent triumph of discovery. In Chile, PS does not seem to be an existing competence in practicing teachers (Felmer\&Perdomo-Diaz, 2016a; Preiss et al., 2011). Furthermore, this weakness adds up to low levels of disciplinary knowledge, which have been reflected in the INICIA test, a test examining the disciplinary and pedagogical knowledge from graduates of different mathematics teaching programs in the country (Mineduc, 2014), as well as in other studies (Varas et al., 2008).

Relating to this, it is worth investigating about the most appropriate strategies to include (c) Psy, Soc, \&Educ, 2017, Vol. 9(1) 
PS in the processes of initial mathematics teacher training, as well as in professional development programs for practicing teachers in order for them to incorporate PS skills into their teaching practices. It is also essential to examine whether these strategies guarantee to any extent that teachers will transfer PS practices effectively and regularly to their classroom practices. This will mean examining how PS strategies and their transfer to classroom are regarded by practicing teachers, in the sense of being valued as viable and relevant strategies, along with assessing if PS strategies can be adjusted to their curriculum requirements. In addition, this assessment also involves examining teachers' beliefs about the nature of mathematics, the learning of mathematics and achievement in mathematics, as well as evaluating possible changes in teachers' beliefs resulting from the implementation of PS strategies.

The RPAula strategy (Felmer\&Perdomo-Diaz, 2016b-c), on which we report in this work, regards a 'problem' as a mathematical activity where the individual performing the activity does not have a method or an algorithm to arrive to a solution of it. That is to say, if a method or an algorithm is known, problems lose their essence, and they are considered 'exercises' (Schoenfeld, 1985). Therefore, problems usually demand a longer investment of time to be answered from the person solving them, and their structure or presentation does not explicitly provide keywords or indications of the operation necessary to solve them (Kloosterman\& Stage, 1992).

In Chile, there is little evidence of professional development strategies that have focused on PS. Even so, a good example of research about PS is the Finland-Chile Study (Araya \&Varas, 2013), which inspired the RPAula proposal. The Finland-Chile Study focused on elements such as persistent and sequenced medium-term work with teachers and classroom observation rather than short and intensive explanatory strategies or strategies with no transfer to the classroom.

The open-ended problems used in Varas' project were compiled in a recently published book (Araya \&Varas, 2013). The book introduces objectives and recommendations for the implementation of Varas' proposal in the classroom, along with experiences of participating teachers. The research conducted so far by Vara's project has demonstrated some outstanding results, such as the increase in self-confidence of teachers, sensitivity to students and teachers' reflections about their own practices when teaching open-ended problems. Although with a different scope, another good example of PS research is the work of Diaz \& Poblete (2009), which also reports a professional development strategy based on PS.

There are other initiatives similar to the RPAula proposal, such as the MProSE project (Mathematical Problem Solving for Everyone), which has been introducing the experience of problem solving in classrooms for several years now (Toh et al., 2013). There is also the Problem-Solving Cycle, which is part of the STAAR project (Supporting the Transition from Arithmetics to Algebraic Reasoning) (Koellner et al., 2008). 


\section{The RPAula Workshop}

The RPAula Workshop is a professional development strategy of 50 hours, divided into 30 hours of face-to-face training, and 20 hours for the implementation of the strategy. The full 50-hour course extends for a year, and participants attend monthly sessions of three or four hours each. During each session, teachers experience PS and develop this key mathematical ability. The experience is mainly characterized by the active participation of teachers working in groups, with subsequent discussions, and joint participation in a plenary activity at the end of the session.

The goal of the RPAula workshop is to incorporate PS in the classroom, by developing PS skills in teachers. Accordingly, the workshop also guides the teachers' knowledge to transfer PS activities into classroom. This is done by means of the activity "Problem Solving Activities in the Classroom" (hereinafter ARPA). The ARPA activity corresponds to a lesson with his students at their own school, that the teacher plans and implements based on what the teacher has experienced during the workshop sessions. Once the teacher has implemented the activity, the supervisor of the workshop reviews and provides feedback regarding the activity. In addition, participants in the workshop reflect collectively about the ARPA activity.

During the workshop, work in randomized groups (Liljedahl, 2014) is preferred as a way to socialize knowledge and participants' respective experiences with ARPA. The creation of random groups aims to break groups that have previously worked together, to promote diversity, to include and to exchange experiences, and to avoid skill-based biases. During their respective implementation processes, teachers replicate the formation of randomized groups with their students.

Thus, the RPAula workshop offers teachers opportunities to reflect about their own abilities to solve problems, about their own mathematical knowledge and about their own learning processes in order to learn and test PS strategies and experience the emotions that may arise during PS tasks. Each session is led by a supervisor, who establishes a supervisor-teacher relationship as a model for future teacher-student relationships, in order to transfer this model into the implementation of ARPA with their own students. This dynamic allows teachers to think about the implementation of ARPA, to analyze the possible effects of the implementation of ARPA, and to anticipate how to carry out the implementation of ARPA in their own classrooms.

The design and implementation of the RPAula strategy is based on two basic principles: to do and to reflect (Marrongelle et al, 2013.). Teachers participate in workshops sessions, and, later, they replicate their experiences in their own pedagogical contexts. The teachers are also requested to reflect on their actions, both on the strategies used to solve the proposed problems as well strategies for transfer to the classroom. They are also asked to think about the emotions and any blocks that may have arisen during the process of resolution. Therefore, through the RPAula program, we create conditions for teachers to be able to assess the problems involved

(c) Psy, Soc, \&Educ, 2017, Vol. 9(1) 
in their own teaching practices and reflect about their own educational practices.

The research presented in this article has the following objectives: 1 . evaluating the impact of the RPAula professional development strategy on teachers' beliefs about the nature of mathematics. Specifically, in respect to their views either of mathematics being a formal discipline or as a process of inquiry; 2.Assessing teachers' changes in their beliefs about learning mathematics, namely, if teachers fundamentally lead the process, or if it is a learning process in which students actively participate; 3.Evaluating teachers' changes in their beliefs about their students' achievements in mathematics; and, finally, 4. Assessing changes regarding PS practices and teachers' beliefs, in respect to appraisal of PS, the implementation of PS activities in the classroom, and teachers' perception of self-efficacy regarding PS and the teaching of PS.

\section{Methods}

\section{Participants}

We assessed a sample of 82 primary-school teachers. The teachers agreed voluntarily to participate or they were asked to participate in the RPAula Workshop by the headmasters of their respective schools. The workshop included the planning and implementation of Problem Solving Classroom Activities (ARPA). The research was quasi-experimental, based on a pretest-posttest design. The objectives of the RPAula proposal and its requirements were previously informed to the educational community involved: teachers, parents, students, and the authorities of the respective educational institutions. Participation was formalized by means of informed consents and informed assents from each participant.

\section{Measures}

To measure the impact of the RPAula Workshop, four questionnaires were applied. The questionnaires were applied at the beginning and at the end of the intervention and their purpose was to capture any changes in the previously defined aspect of interest for this research.

In order to measure the beliefs about the nature of mathematics, the beliefs about the learning of mathematics, and the beliefs about achievement in mathematics, three questionnaires from the TEDS-M (Teacher Education and Development Study: Learning to Teach Mathematics) were used (Tatto, 2013). This study was the first large-scale study assessing recently graduated mathematics teachers or students from mathematics teaching programs close to graduation from 17 countries, including Chile (Avalos \&Matus, 2010). The items on these three questionnaires were measured using 6-point Likert type-scales, from 1"strongly disagree" to 6- "strongly agree".

The first questionnaire was titled CNAM questionnaire and it explored the beliefs about the nature of mathematics. This questionnaire measured two dimensions: the first dimension assessed the formalist view of mathematics and it consisted of 6 items. The second dimension explored the perspective of mathematics as being a process of inquiry and it included 5 items. 
These two dimensions were based on traditionally opposing conceptions about the nature of mathematics, namely, a perspective that considers that mathematics can be dynamic (meaning that mathematics involve change and creativity), and an opposing perspective, that understands mathematics as a fixed, rigorous and rule-based discipline (Tang \& Hsieh, 2014).

The factorial analysis corroborated this two-dimensional structure, presenting appropriate fit indices: $\chi^{2} \mathrm{SB}=85.4819 ; \mathrm{p}=.000$; NNFI $=.912$; CFI $=.929$; RMSEA $=121$; IC (107 - 056). The value of Kaiser-Meyer-Olkin (KMO) was .866 and the value for Bartlett's sphericity test was $1835.8(\mathrm{df}=66 ; \mathrm{p}=.00001)$. Moreover, the reliability index for the dimension referred to the view of mathematics as a formal discipline was estimated to be .889, and for the dimension of mathematics conceived a process of inquiry, it was estimated to be .835. Cronbach's alpha coefficients for the dimension referred to the view of mathematics as a formal discipline were .79 and for the dimension concerning the perspective of mathematics as a process of inquiry, they were .89. Alltheseindices are consideredveryadequate (Hu\&Bentler, 1998).

The second questionnaire was titled CAPM questionnaire and it measured beliefs about the learning of mathematics. This questionnaire was organized according to two dimensions. The first dimension referred to teacher-guided learning and it included 7 items. The second dimension assessed active learning and it consisted of 6 items. These two dimensions were based on opposing views. Namely, a perspective centered on knowledge transfer, and an opposing perspective centered on students, which included a constructionist perspective about learning (Tang \& Hsieh, 2014).

Factor analysis confirmed the existence of these two dimensions, presenting appropriate fit indices: $\chi^{2} \mathrm{SB}=159.5643$; $\mathrm{p}=.000$; NNFI $=.954$; CFI $=.963$; RMSEA $=.072$; IC (.058 $.085)$. The value for the Kaiser-Meyer-Olkin test (KMO) was .854 and the value for Bartlett's sphericity test was 1445.7 ( $\mathrm{df}=78 ; \mathrm{p}=.00001$ ). Moreover, the reliability index for the active learning dimension was estimated to be .894 and, for the dimension of teacher-directed learning, it was estimated to be .838. Cronbach's alpha coefficients were .76 for the dimension of teacher-directed learning and .89 for the dimension of active learning. All these indices are considered very adequate in the literature (Hu \&Bentler, 1998).

The third questionnaire was titled CLA questionnaire and it was designed to measure beliefs about achievement in mathematics learning. This questionnaire contained 8 items that measured a single dimension, which we were designated as Perspective about mathematical skills perceived as immutable abilities, which is a view that opposes to the belief that mathematical abilities can be developed (Tang \& Hsieh, 2014; Avalos \&Matus, 2010, p.114). In the case of this questionnaire, factor analysis showed optimal fit indices: $\chi^{2} \mathrm{SB}=85.4819$; $\mathrm{p}$ $=.000$; NNFI $=.963$; CFI $=.974$; RMSEA $=.106$; IC $(.083-.129)$. The value for the KaiserMeyer-Olkin test (KMO) was .875 and the value for Bartlett's sphericity test was 1016.2 (df = 28; $\mathrm{p}=.00001$ ). Moreover, the reliability index was estimated to be .90 . Again, these values of goodness of fit are considered very adequate.

To measure the dimensions related to PS, a questionnaire, titled CPRP questionnaire, concerning beliefs and activities related to PS was used. This questionnaire was developed by the research team to measure teachers' self-reports about their practices and beliefs in relation 
to PS. The items about teaching practices were developed based on research about studentcentered teaching (e.g. Swan, 2006), autonomy-supportive climate (e.g. Leroy, Bressoux, Sarrazin\&Trouilloud, 2007), and inquiry-based learning (e.g. Engeln, Euler \&Maass, 2013). The dimensions assessing beliefs were mainly developed based on the works of Bandura (2006), Stipek et al. (2001), and Leroy et al. (2007). The initial version of the CPRP questionnaire was outlined based on five dimensions, namely: Student-centered PS practices, with 13 items; Teacher-centered PS practices, with 5 items; Self-efficacy in PS, with 5 items; Self-efficacy in teaching PS, with 6 items, and, finally Value and importance of PS, with 5 items. The dimensions concerned with teaching practices were measured using frequency Likert type-scales, from 1- "Never" to 6- "Always", while the dimensions regarding beliefs were measured using Likert type-scales, with levels of agreement from 1- "strongly disagree" to 6- "strongly agree".

In addition, in the first part of the questionnaire, teachers provided their respective demographic data, such as gender, teacher training and teacher experience, as well as data about their class, such as number of students, educational level, and frequency of use of PS in mathematics. Factor analysis corroborated the 5-dimensional structure originally proposed. The model showed a very adequate fit to the data, as suggested by the fit indices: $\chi^{2} \mathrm{SB}=844.1742$; $\mathrm{p}=.000$; CFI =.979; NNFI =. 977, RMSEA =.050; IC (.045 - .056). The value for the KaiserMeyer-Olkin test (KMO) was .911 and the value for Bartlett's sphericity test was $5848.1 \mathrm{df}=$ 528; $\mathrm{p}=.00$ ). Moreover, the reliability index was estimated to be adequate, showing a Cronbach's alpha coefficient of .936 and a McDonald's coefficient omega of .912. Cronbach's alpha coefficients for the five dimensions varied between .77 and .91. All these indices are considered very adequate in the literature (Hu \&Bentler, 1998).

\section{Results}

After having validated the factorial dimensions of the questionnaires applied to the teachers, an analysis of related samples was conducted to assess the scores obtained before and after the workshop. This analysis was carried out to evaluate if there were any differences between the before and after scores, and to examine the impact of the RPAula professional development strategy. T-tests for related samples were applied to the dimensions that met the assumption of normality (tested using the Kolmogorov-Smirnov test). In the case of the dimensions or subgroups that violated the assumption of normality, the Wilcoxon signed-rank test was applied to test medians and to determine whether there were any significant differences. The Wilcoxon signed-rank test requires having ordinal levels for the dependent variable, which was met by the questionnaires previously introduced. Below, the results of these analyses are presented. The subscripts "pre" and "post" will be used to indicate the time of measurement for the parameters aforementioned.

\section{Concerning the beliefs about the nature of mathematics (CNAM questionnaire)}

The CNAM questionnaire has two dimensions. With regard to the dimension concerning 
the formalist perspective of mathematics, it is observed that the RPAula strategy had a positive impact, because it significantly diminished the view of mathematics as being a rigid, structured and eminently formal discipline $\left(\mathrm{Ma}_{\text {pre }}=24.06, \mathrm{DS}_{\text {pre }}=4.97 ; \mathrm{M}_{\text {post }}=20.52, \mathrm{DS}_{\text {post }}=5.95 ; \mathrm{t}\right.$ $(81)=6.009, \mathrm{p}<.01$, CI 2.366 to 4.708$)$. The changes in specific CNAM questionnaire dimension items are presented below.

Table 1.CNAM questionnaire, first dimension.

Items

WilcoxonZ $\quad \mathrm{p}<\ldots$

Mathematics is a collection of formulas and procedures that prescribe how to solve a problem

Mathematics presupposes the recall and application of definitions, formulas, facts and mathematical procedures

In order to solve a mathematical task, one must know the correct procedure and, if not, one can get lost

The core of mathematics is its logical rigorousness and its precision

Mathematical work requires many hours of practice and the correct application of routines and strategies to solve problems

Mathematics entails learning, recalling and application

$-2.443$

0.01

On the other hand, as to the second dimension of the CNAM questionnaire, which was concerned with the view of mathematics as a process of inquiry, score differences between the pre and post conditions did not show any significant differences that could be attributed to the application of the RPAula Workshop (WilcoxonZ $=1.851, \mathrm{p}>.05$ ). However, it was possible to observe a favorable change in the responses for two items, which might indicate an effect of having been able to experience personally the PS process of discovery, which led to the appraisal of PS due to teachers' participation in the RPAula Workshop. Thesetwoitems are presentedbelow.

Table 2.CNAM questionnaire, second dimension.

\begin{tabular}{lcc}
\multicolumn{1}{c}{ Items } & WilcoxonZ & $\mathrm{p}<\ldots$ \\
\hline In mathematics, there are many things that one can discover and test & 2.351 & 0.05 \\
Many aspects of mathematics have practical applications & 2.667 & 0.01 \\
\hline
\end{tabular}

\section{Concerning the beliefs about the learning of mathematics (CAPM questionnaire)}


The CAPM questionnaire consisted of two dimensions. With regard to the dimension about teacher-directed learning, it appears that the differences between the total scores from the pre and post conditions indicate a positive impact of the implementation of the RPAula Workshop. Namely, it was found that the beliefs about the learning of mathematics being teacher-directed decreased (Wilcoxon $\mathrm{Z}=-3.979, \mathrm{p}<.01$ ). This change can be observed when analyzing the answers to the following items, which significantly decreased in respect to their initial levels.

Table 3.CAPM questionnaire on teacher-directed learning.

\begin{tabular}{lcc}
\hline \multicolumn{1}{c}{ Items } & WilcoxonZ & $\mathrm{p}<\ldots$ \\
\hline Students learn mathematics better if they pay attention to teacher explanations & -2.694 & 0.05 \\
When students work on mathematical problems, it is more important to emphasize on & \multirow{2}{*}{0.667} & 0.05 \\
obtaining a correct solution, rather than on the process involved to arrive to a solution & & \\
\hline
\end{tabular}

In parallel, in respect to the dimension that assessed active learning in mathematics, it was observed that the differences between the total scores for the pre and post conditions did not report significant differences resulting from the application of the RPAula Workshop (Wilcoxon $\mathrm{Z}=0.742, \mathrm{p}>.05$ ). However, it was possible to see a favorable change in two items as seen below.

Table 4.CAPM questionnaire on active learning.

\begin{tabular}{lcc}
\multicolumn{1}{c}{ Items } & WilcoxonZ & $\mathrm{p}<\ldots$ \\
\hline Teachers must help their students to find their own strategies for solving mathematical & 2.162 & 0.05 \\
problems & & \\
Teachers must stimulate their students to find their own solutions to mathematical & 2.031 & 0.05 \\
problems, even when those solutions may not be fully adequate & &
\end{tabular}

\section{Concerning the beliefs about achievement in mathematics (CLA questionnaire)}

Regarding the single dimension of the CLA questionnaire, which assessed beliefs associated with achievement in mathematics (vision of mathematical abilities as being immutable), the analysis showed that the RPAula Workshop had a positive impact on teachers' perceptions. In particular, it significantly lessened the perspective that access to mathematical learning was a fixed condition, associated with innate abilities of students, gender or ethnicity $\left(\mathrm{M}_{\text {pre }}=20.01, \mathrm{DS}_{\text {pre }}=6.03 ; \mathrm{M}_{\text {post }}=17.83, \mathrm{DS}_{\text {post }}=5.59 ; \mathrm{t}(81)=3.483, \mathrm{p}<.01, \mathrm{CI} .936\right.$ to 3.430). This change was observed in the answers to the items given below. 
Table 5. CLA questionnaire.

Items

Only the more skillful students are able to participate in problem-solving activities that require multiple steps

In general, male students are naturally better at mathematics than female students

Some people are good at mathematics, while others are not

Some ethnic groups are better at mathematics than others

WilcoxonZ $\quad \mathrm{p}<\ldots$

$-3.364$

0.01

$-3.008$

0.01

$-3.206$

0.01

$-3.833$

0.01

\section{Concerning practices and beliefs related to solving non-routine problems (CPRP questionnaire)}

The CPRP questionnaire consisted of 5 dimensions. When analyzing the effect of the RPAula Workshop regarding the pre and post conditions and their scores, we found that the RPAula program had a positive effect on the dimension of PS practices centered on the students. Namely, the level of agreement with statements associated with student-centered perspectives, emphasizing the active role of the students, increased (Wilcoxon $Z=5.275$, $p<$ $.01)$. Among the significant changes in this dimension, we can find:

Table 6.CPRP questionnaire, PS practices centered on the students.

\begin{tabular}{lcc}
\multicolumn{1}{c}{ Items } & WilcoxonZ & $\mathrm{p}<\ldots$ \\
\hline My students solve their problems independently & 4.821 & 0.01 \\
My students are able to express different strategies to solve problems, even when & 4.173 & 0.01 \\
those strategies may be wrong & 2.80 & 0.01 \\
I am usually surprised by my students' ideas & 5.715 & 0.01 \\
My students are able to discuss with each other different ways to solve non-routine & & 0.01 \\
problems & 5.130 & 0.01 \\
I conduct plenary discussions, which include all students & 5.833 & 0.01 \\
My students are able to come up with different problem solving strategies & 5.253 & 0.01 \\
My students ask interesting questions & 5.506 & -2.140 \\
My students discuss their own mistakes & 0.01 \\
I continuously ask questions to my students & 4.777 & 0.01 \\
My students explore new problems arising from the problems we are working on & & 0.01 \\
\hline
\end{tabular}


On the other hand, with regard to the PS teacher-centered dimension, a positive effect from the RPAula Workshop was found on teachers' perceptions, by reducing the degree of agreement with statements associated with this perspective (Wilcoxon $Z=-5.275$; $p<.01$ ). This can be observed in the four items shown below.

Table 7.CPRP questionnaire, PS teacher-centered

\section{Items}

WilcoxonZ $\quad \mathrm{p}<\ldots$

If my students take too long to arrive to the solution of a problem, I solve it on the whiteboard

$-3.653 \quad 0.01$

My students greatly depend on my help during the process of solving a problem $-2.256$ 0.01 If a student is too frustrated with a problem, I show the student how to solve it $-5.193 \quad 0.01$ My students are very slow when solving problems

$-4.033$ 0.01

Similarly, in the dimension referring to the self-efficacy in PS, the differences in total scores observed between the pre and post conditions showed a positive impact of the implementation of the RPAula Workshop (Wilcoxon $\mathrm{Z}=6,102, \mathrm{p}<.01$ ). Details of the changes found in the five items presented below.

Table 8. CPRP questionnaire, self-efficacy in PS.

$$
\text { Items }
$$

WilcoxonZ $\quad \mathrm{p}<\ldots$

When I read a non-routine problem one or more times, I am able to understand what it says

2.131

0.05

I can solve non-routine mathematics problems

5.443

0.01

I can developed different strategies to try to solve a non-routine mathematical problem

5.742

0.01

I can argue for the correct solution of a non-routine problem

5.056

0.01

I can explain to a different person how I solved a non-routine problem

4,925

0,01

In the fourth dimension of the CPRP questionnaire, which concerned self-efficacy when teaching PS, a positive effect of the RPAula Workshop was also found in respect to total pre and post scores of teachers' perceptions (Wilcoxon $\mathrm{Z}=6.102, \mathrm{p}<.01$ ). The main effects of the changes in this dimension are presented in the items below.

Table 9.CPRP questionnaire, self-efficacy when teaching PS. 


\begin{tabular}{lcc}
\hline \multicolumn{1}{c}{ Items } & WilcoxonZ & $\mathrm{p}<\ldots$ \\
\hline I can successfully plan and implement a non-routine problem activity & 5.614 & 0.01 \\
I am able to guide students with different levels of progress during a problem-solving & 5.193 & 0.01 \\
activity & 4.326 & 0.01 \\
I can motivate my students to work on the solution of non-routine problems & 0.01 \\
I am capable of guiding a student into arriving to a solution to a problem in a way that \\
$\begin{array}{l}\text { the student can be independent } \\
\text { I can cover curriculum contents and regularly carry out non-routine problem }\end{array}$ \\
resolution activities & 2.031 & 0.01 \\
\hline
\end{tabular}

Finally, with regard to the last dimension of the CPRP questionnaire, which assessed the value and importance of PS, the differences between the total scores from the pre and post conditions did not show that the RPAula Workshop had a positive impact on the appraisal of PS (WilcoxonZ $=1.770, \mathrm{p}>.05$ ). One possible explanation for this may be that despite teachers' positive evaluation of the RPAula workshop experience, the teachers failed to see an effective value in use for PS or they could not come up with strategies to incorporate or transfer PS methodology directly into your their planning or traditional classes. This perception can be observed in result changes in some items; namely, items where teachers assessed positively some aspects of the workshop, which could be regarded as complementary to their traditional activities.

Table 10. CPRP questionnaire, the value and importance of PS.

\begin{tabular}{lcc}
\hline \multicolumn{1}{c}{ Items } & WilcoxonZ & $\mathrm{p}<\ldots$ \\
\hline Non-routine problems are good for motivating students & 2.817 & 0.01 \\
I can work with non-routine problems with less-skilled students & 2.444 & 0.05 \\
\hline
\end{tabular}

\section{Discussion}

The results obtained from the RPAula workshop intervention are encouraging. Namely, changes in teachers' beliefs were specially emphasized because it is a known fact that teachers' beliefs about mathematics influence students' beliefs about mathematics (see, i.e., Duffy, Muis, Foy, Trevors, \&Ranellucci, 2016). Likewise, it has also been established that the beliefs held about the nature of mathematics are linked to learning, academic performance and motivational constructs (Muis, 2004). Therefore, it could be predicted that the changes found in teachers' beliefs could have a positive impact on students. This is an aspect that will be taken into consideration in future research within this framework, which includes the RPAula Workshop.

It is worth mentioning that within Chilean society in general, and replicated in classrooms, there is a dominant, but not necessarily verbalized idea by teachers, students and 
families that mathematics is a set of calculation procedures, rules, regulations, formulas, repetitive exercises, and techniques to solve problems. This conception is part of what is known as a formalist vision of mathematics (Alcalá, 2002). Within this conception of mathematics, mathematical knowledge can be transmitted directly through verbal explanations and continuous exercises.

For this reason, the finding of significant differences in beliefs about the nature of mathematics (formalist view of mathematics, CNAM questionnaire) and beliefs about learning mathematics (teacher-directed learning, CAPM questionnaire) as a result of teachers' participation in the RPAula Workshop is very important. Namely, the discovery of a decrease in the degree of adherence to the formalist conception of mathematics is highly relevant. Similarly, it was found a decrease in the level of acceptance towards the items related to beliefs about teacher directed-learning of mathematics, in which students primarily pay attention to teachers' explanations, with an emphasis on achieving pre-established techniques to arrive at the correct answer.

These results are also consistent with the changes found in the practical dimension of teacher-centered problem-solving (CPRP questionnaire), where teachers reported a lower frequency of teacher-centered practices after the RPAula Workshop. In respect to this point, it is important to mention that these beliefs are not negative or bad in themselves, as mathematics has rigorous aspects and some of these aspects are related to conventions and rules. That is to say, teacher-directed learning can be very appropriate in certain contexts. Even so, in the Chilean context, where work in mathematics classes focuses namely on practicing procedures (Preiss et al. 2011), it is highly valuable that teachers can challenge such beliefs and reduce teacher-centered practices. Another dimension where changes were observed was in studentcentered problem-solving practices. Teachers reported changes in their practices towards the development of skills such as problem solving, although they did not show any changes in their associated beliefs.

Regarding the dimensions associated with self-efficacy, the RPAula strategy had a positive impact in the perception of teachers about their competence and self-efficacy at implementing PS in the classroom with their own students (self-efficacy dimensions in PS and self-efficacy in teaching PS). Teachers felt that they could design or plan PS activities and link them with curricula from specific educational levels. Additionally, by modifying their role of being the central pillars during students' learning processes, teachers were able to allocate time and attention for their students to inquire and explore their own problem solving strategies, promoting an improvement in students' self-concepts, skills and resources for learning mathematics. In addition, this workshop diminished teachers' urgency in requesting solutions to problems, which produces mental blocks in students. Teachers also decreased their perceived loss in curriculum planning or loss in mathematical content. This view was replaced by a perception of new learning opportunities, because they themselves experienced initial mental blocks. When this occurred, supervisors would ask teachers guiding questions instead of providing them with solutions to the problems.

The changes experienced by the group of teachers who participated in the first experimental version of the RPAula Workshop are promising pieces of evidence about the (c) Psy, Soc, \&Educ, 2017, Vol. 9(1) 
effectiveness of the workshop as an alternative for professional development. The importance of reporting these results is that this initiative falls within the framework of educational efforts to provide evidence-based strategies; that is to say, practices or activities supported by rigorous research. Even when the group of participating teachers came from different educational realities and had diverse sets of resources available, the results obtained are encouraging. Thus, these findings also indicate the versatility of the RPAulaWorskhop as an option for the improvement of multiple educational contexts. The workshop RPAula can therefore be considered as a professional development strategy, which can be complemented by the acquisition of new disciplinary and pedagogical knowledge (Felmer and Perdomo-Diaz, 2015bc).

Finally, it is important to mention that the general project including the RPAula Workshop has implemented a permanent repository at www.arpamat.cl, where anyone can extract more information about the ARPA activity reported in this paper.

\section{Acknowledgments}

This research was partially funded by FONDEF project (ID14I10338), and the Program of Basal Financing (PFB 0003) from the Government of Chile. V. Giaconi was partially funded by CONICYT-PCHA/National PhD scholarship / 2013, 21130684. J. Perdomo-Díaz was partially funded by Conicyt-Fondecyt 3140597 project.

\section{References}

Alcalá, M. (2002). La construcción del lenguaje matemático. Barcelona: Graó.

Araya, P., \& Varas, L. (2013). Resolución de Problemas de final abierto en clases de Matemática. Santiago: CIAE, Universidad de Chile.

Ávalos, B., \& Matus, C. (2010). La formación inicial docente en Chile desde una óptica internacional. Informe nacional del Estudio Internacional IEA TEDS-M. Santiago de Chile: Ministerio de Educación.

Bandura, A. (2006). Guide for constructing self-efficacy scales. Self-efficacybeliefs of adolescents, 5, 307-337.

Díaz, V. \& Poblete, A. (2009). Competencias y Transposición Didáctica: Binomio para un efectivo perfeccionamiento en Matemática. Investigación y Postgrado, 24(2), 77-107.

Duffy, M. C., Muis, K. R., Foy, M. J., Trevors, G., \&Ranellucci, J. (2016). Exploring Relations between Teachers' Beliefs, Instructional Practices, and Students' Beliefs in Statistics.International Education Research, 4(1), 37-66. http://dx.doi.org/10.12735/ier.v4i1p37

Engeln, K., Euler, M., \&Maass, K. (2013). Inquiry-based learning in mathematics and science: A comparative baseline study of teachers' beliefs and practices across 12 European countries. ZDM The International Journal on Mathematics Education , 45(6), 823-836.

Felmer, P., \&Perdomo-Díaz, J. (2016a) Novice Chilean Secondary Mathematics Teachers as 
Problem Solvers.In Felmer, Pehkonen and Kilpatrick (Eds.).Posing and Solving Mathematical Problems: Advances and New Perspectives. Research in MathematicsEducation Series. Springer, pp. 287-308.

Felmer, P., \& Perdomo-Díaz, J. (2016b) Un programa de desarrollo profesional docente para el nuevo currículo de matemática: La resolución de problemas como eje articulador. Revista Educación Matemática, in Press.

Hu, L.-T., \&Bentler, P. M. (1998). Fit indices in covariance structure modeling: Sensitivity to underparameterized model misspecification. Psychological Methods, 3, 424-453.

Kloosterman, P \& Stage, F. K. (1992). Measuring Beliefs About Mathematical Problem Solving. School Science and Mathematics, 92(3), 109-115.

Koellner, K., Schneider, C., Roberts, S., Jacobs, J., \&Borko, H. (2008).Using the ProblemSolving Cycle model of professional development to support novice mathematics instructional leaders.In F. Arbaugh\& P. M. Taylor (Eds.), Inquiry into Mathematics Teacher Education. Association of Mathematics Teacher Educators (AMTE) Monograph Series, (v. 5), 59-70.

Leroy, N., Bressoux, P., Sarrazin, P., \&Trouilloud, D. (2007).Impact of teachers' implicit theories and perceived pressures on the establishment of an autonomy supportive climate.European Journal of Psychology of Education, 22(4), 529-545.

Liljedahl, P. (2014). The affordances of using visually random groups in a mathematics classroom. In Y. Li, E. Silver, \& S. Li (Eds.) Transforming Mathematics Instruction: Multiple Approaches and Practices. New York, NY: Springer.

Marrongelle, K., Sztajn, P., \& Smith, M. (2013).Scaling up professional development in an era of common state standards.Journal of TeacherEducation, 64(3), 202-211.

Mineduc (2012). Bases Curriculares para la Educación Básica. Unidad de Currículum y Evaluación. Ministerio de Educación, Gobierno de Chile.

Mineduc (2014). Resultados Evaluación INICIA 2014. Ministerio de Educación, Gobierno de Chile.

Muis, K. R. (2004). Personal epistemology and mathematics: A critical review and synthesis of research. Review of educational research, 74(3), 317-377.

National Research Council (2001). Adding it up: Helping children learn mathematics. J. Kilpatrick, J. Swafford, and B. Findell (Eds.). Mathematics Learning Study Committee, Center for Education, Division of Behavioral and Social Sciences and Education. Washington, DC: National Academy Press.

Niss, M. (2002).Mathematical competencies and the learning of mathematics: the Danish KOM project. [http://w3.msi.vxu.se/users/hso/aaa_niss.pdf]

Perdomo-Díaz, J. Felmer, P., (2016c) El taller RPAula: Activando la resolución de problemas en las aulas. Profesorado: Revista de Currículum y Formacióndel Profesorado, in Press.

Polya, G. (1954). How to Solve It. Princeton, Princeton University Press.

Preiss, D., Larraín, A., \& Valenzuela, S. (2011). Discurso y pensamiento en el aula matemática chilena. Psykhe (Santiago), 20(2), 131-146.

Schoenfeld, A. (1985). Mathematical Problem Solving. Academic Press, Inc., Harcourt Brace Jovanovich, Publishers. 
Stipek, D.J., Givvin, K.B., Salmon, J.M. \&MacGyvers, V.L. (2001). Teachers' beliefs and practices related to mathematics instruction. Teaching and Teacher Education, 17, 213226.

Swan, M. (2006). Designing and using research instruments to describe the beliefs and practices of mathematics teachers. Research in Education, 75(1), 58-70.

Tang, S. J., \& Hsieh, F. J. (2014). The Cultural Notion of Teacher Education: Future Lower Secondary Teachers' Beliefs on the Nature of Mathematics, the Learning of Mathematics and Mathematics Achievement. In International Perspectives on Teacher Knowledge, Beliefs and Opportunities to Learn (pp. 231-253).Springer Netherlands.

Tatto, M. T. (Ed.). (2013). The Teacher Education and Development Study in Mathematics (TEDS-M): Policy, practice, and readiness to teach primary and secondary mathematics in 17 countries. Technical report. Amsterdam: IEA.

Toh, T. L., Quek, K. S., Tay, E. G., Leong, Y. H., Toh, P. C., Ho, F. H. \&Dindyal, J. (2013). Infusing Problem Solving into Mathematics Content Course for Pre-service Secondary School Mathematics Teachers.TheMathematicsEducator, 15(1), 98-120.

Varas, L., Felmer, P., Gálvez, G., Lewin, R., Martínez, C., Navarro, S., Ortiz, A., \&Schwarze, G. (2008). Oportunidades de preparación para enseñar matemática de futuros profesores de educación general básica en Chile. Calidad en la Educación, Consejo Superior de Educación, 29, 63-88. 